\title{
Green banking practices and sustainable energy in Dhaka city
}

\author{
P. Shah ${ }^{1}$ \& S. M. Ahsan Habib ${ }^{2}$ \\ ${ }^{1}$ University of Liberal Arts [ULAB], Bangladesh \\ ${ }^{2}$ Bangladesh Institute of Bank Management [BIBM], Bangladesh
}

\begin{abstract}
Environmental concern is at the center of green banking practices. The public concern of the state of the environment has been growing rapidly in the last few years mostly due to apparently unusual weather patterns, rising greenhouse gases, declining air quality, declining non-renewable energy resources, etc. In particular, cities like Dhaka are severely affected with the changing environment and unsustainable energy situation. Banks hold a unique position in an economic system that can affect production, business, and other economic activities through their financing activities. Alongside handling environmental risks, banks may contribute by saving energy resources in their own operations and may also influence their clients to save energy resources. In Bangladesh, a lot is to be done to attain the expected level of environmental standard; however, remarkable development has taken place in terms of green banking practices. The broad objective of the conference paper is to evaluate the relevance of green banking practices for attaining energy sustainability in Dhaka city. The study observes that banks can play critical roles in attaining energy sustainability in Dhaka city through green activities.
\end{abstract}

Keywords: green banking, environmental responsibility of bank, sustainable energy, renewable energy, sustainable banking.

\section{Introduction}

An increasing number of banks around the world are going green by offering innovative green products; saving resources and supporting activities that help conserve the environment. 'Conserving Environment' through operation and financing is at the centre of Green Banking (GB) activities of a bank. Such a 
bank is expected to use its resources with responsibility avoiding waste and giving priority to the environment and society. Alongside handling environmental risks in their day-to-day operation and financing activities, banks may contribute in attaining sustainable energy planning in an economy.

Cities command an increasingly dominant role in the global economy as centers of both productions and consumption. In the case of most developing countries, rapid urban growth is surpassing the capacity of most cities to provide adequate critical services like energy to their citizens. While there is no 'typical' city in terms of their energy needs and energy use, they do have a lot in common. In most cases, cities are burning fossil fuels and contributing massively to the concentration of greenhouse gases in the atmosphere. At present, energy producing resources like fossil fuel, gas, coal, and uranium have reached their peak position. It is predicted that those non-renewable energy sources are going to decline from that position in every location of the earth sooner rather than later. Today, cities in developing countries like Dhaka are severely affected due to the changing environment and unsustainable energy situation.

The global energy crisis coupled with the threats of climate change bring into sharp focus both opportunities and challenges for developing countries [9]. There is no option but for developing countries to have to address the increasing energy demands of growing economies by planning and strategizing sustainable energy. A number of stakeholders in global economies like governments, international organizations, environmental NGOs, media, etc., are working towards that. As one of the stakeholders, banks can also contribute. It is very much within the reach of a number of countries when an increasing number of banks are going green to conserve the environment, popularly called a 'Green Bank' or a 'Sustainable Bank’ or an 'Environmentally Responsible Bank’.

In Bangladesh, there is a lot to be done to attain the expected level of environmental standard, however, remarkable development has taken place in terms of green banking practices in the country. The development has occurred mainly in response to the remarkable initiatives undertaken by the central bank. Commercial banks' responses are crucial for positive outcomes of these initiatives. In connection with the energy issue, the 'Green Banking Policy and Strategy' framework of the Central Bank of Bangladesh requires banks to save energy resources and finance the renewable energy sector. The Central Bank is also offering refinancing facilities to the commercial banks to finance the renewable energy sector of the country. As a measure to handle the energy problem of Dhaka city, there is no doubt that sustainable energy planning and implementation is the need of the time. And in this connection, green banking might be a critical positive force not only to handle the growing energy demand but also to minimize environmental degradation.

The broad objective of the conference paper is to evaluate the relevance and potentials of green banking practices for attaining energy sustainability in Dhaka city. The specific objectives of the paper are: one, to identify the green policy initiatives by Bangladesh Bank and examine the responses of the commercial banks; two, to examine the availability and the status of energy use in Dhaka city; and three, to examine the potential and relevance of green banking practices 
in attaining energy sustainability in Dhaka city. The study is based on secondary information that identifies the existing and potential role of banks in attaining energy sustainability in Dhaka city.

\section{Green banking and sustainable energy: conceptual issues}

Green banking initiatives have been linked with the concepts of market failurepublic goods and externalities. The concepts of externalities and public goods are closely associated. Environmental harm like air pollution, water pollution, land contamination, global warming, etc. have negative externalities. The results of these changed climate, polluted air, polluted water, disrupted eco-system, etc. are Global Public Bads (GPBs) that affect society negatively. The negative externalities and GPBs are the burdens of the entire society. The green initiatives to handle these negative externalities and GPBs are Global Public Goods (GPGs) that are beneficial for entire global communities [1]. Green banking is one of such initiatives. A Green Bank can directly and indirectly contribute to a sustainable environment by following environmental standards and by influencing production and consumption (figure 1).

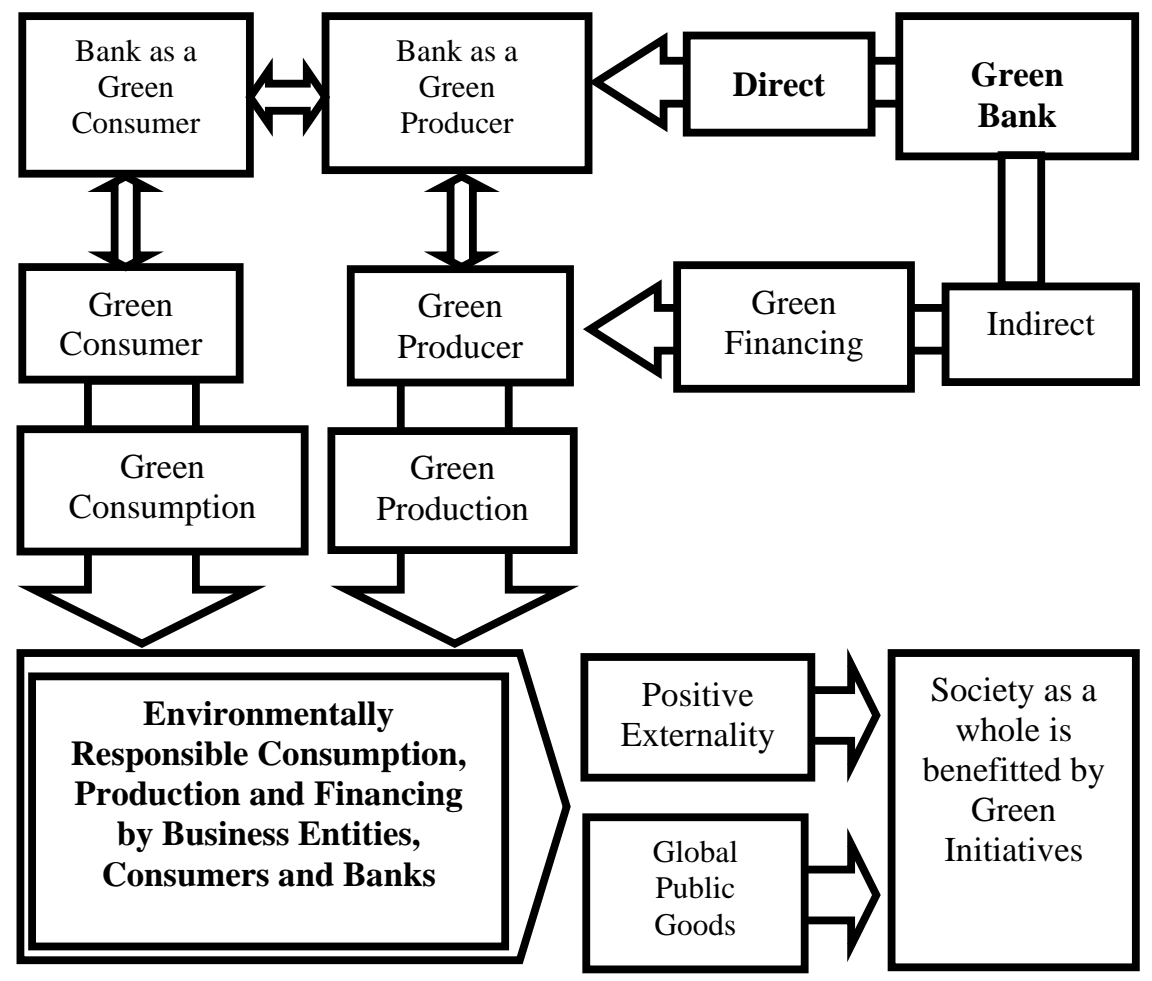

Figure 1: Green banking and sustainable environment. 
Broadly, green banking constitutes of five pillars (figure 2). The first is related to the green vision; the second and third pillars are connected with banks' in-house activities and operation and financing; and the remaining pillars are concerned with supporting other stakeholders and reporting of green activities. All these pillars are integrated and crucial to ensure sustainable green banking. Of these, pillar 2 and 3 are particularly related to the issue of 'sustainable energy'.

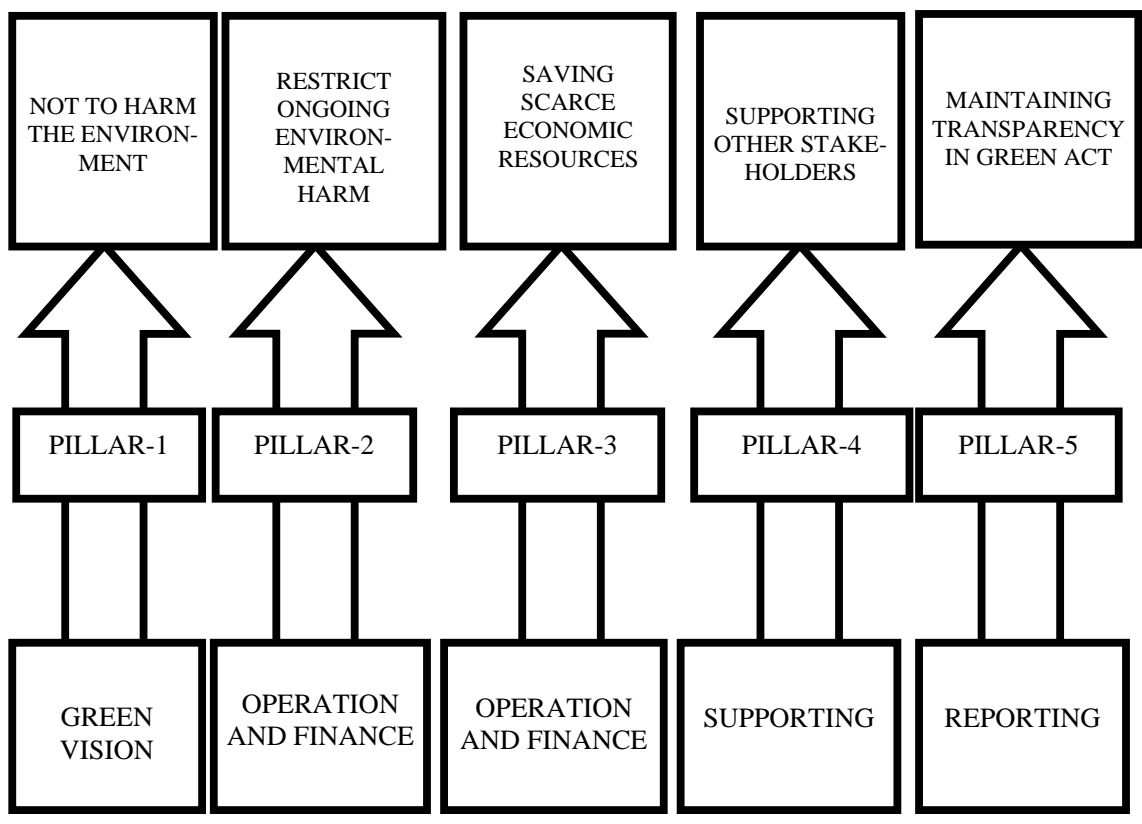

Figure 2: $\quad$ Five pillars of green banking.

The available information on energy use and GHG emission in the global economy indicate a concerning picture. According to the International Energy Agency [5], presumably, global urban populations are mainly responsible for GHG emissions due to their consumption of a bulk amount of energy for the mechanical lifestyle. While, in contrast, still 1.3 billion people in the world live without access to electricity and 2.7 billion have no access to clean cooking facilities. Admittedly, an energy crisis will happen in the future and then urban inhabitants will suffer more compared to rural people [5]. In handling the issues as part of green banking activities, banks are expected to save energy resources in its own operation and finance renewable energy productions. Through green banking, a bank can not only improve its environmental standard it can also create pressure on its clients to undertake only those initiatives that are not environmentally harmful. Today, a number of global banks are getting involved in different green projects that are connected with sustainable energy. For example recently, Foresight Group and the UK Green Investment Bank plc have 
announced the investment of USD20 million to build the Evermore Renewable Energy 15.8MW power station, which is expected to become operational during 2015, and is forecast to be the largest renewable energy project in Northern Ireland. Over the estimated 20 year lifetime of the project, it is expected to supply renewable electricity equivalent to the needs of more than 25,000 homes a year. The project saves the same amount of carbon as taking around 77,000 cars off the road (http://www.greeninvestmentbank.com). Policy makers are also offering support and incentive to the green banks. For example, using government support, small and local financial institutions and banks in the USA and some other European countries have led the way in embracing green development and creating targeted green lending programs. These programs use public subsidies to reduce interest rates on loans issued by participating lenders that homeowners use to finance energy-efficient improvements. In the USA, The Department of Natural Resources subsidizes one-half of the financing for the energy-efficient improvements, making the loan more affordable [2].

Financing and investing in renewable energy makes economic sense, apart from its contribution to emission reductions. According to the International Energy Agency [5], globally, projected investments of USD 630 billion in the renewable energy sector by 2030 would translate into at least 20 million additional jobs - 2.1 million in wind energy, 6.3 million in solar photovoltaic, and 12 million in biofuels-related agriculture and industry. Apart from its higher direct job creation potential, renewable energy is also expected to secure jobs in industries by reducing related emissions and by reducing the costs of production. The prospect of investing in the renewable sector at the country level is encouraging in some developing countries such as China and India. The Clean Development Mechanism (CDM) has helped expand the reach of renewable energy projects for power production to a number of low-income countries such as the Democratic Republic of the Congo, Madagascar, Mauritius, Mozambique, Mali, and Senegal [5].

Today, it is obvious that the use of energy, the types of energy used and the lack of access to sufficient energy have far reaching implications for a city's economic development, its environmental health and for the poor. Cities which implement sustainable energy and climate action plans reduce their vulnerability to energy scarcity. The aims of a sustainable energy action planning are optimal energy-efficiency, low- or no-carbon energy supply, equitable and good energy service provision to users. As identified by UNEP, a 'sustainable energy action planning' helps improving air quality, contributes saving financial resources, helps creating new jobs, and contributes in local economic development [10]. Considering the advantages, it can be said that sustainable energy action planning is the need of the time.

\section{Energy use and power scarcity in Bangladesh with special reference to Dhaka city}

Dhaka is one of the world's fastest growing cities. Dhaka's population is likely to increase from 13.5 million in 2007 to 22 million by 2025, despite the fact that 
now it has a declining fertility rate [8]. This rapid urbanization has taken place in last 25 years and 50 percent of these populations live below poverty level. The major portions of this population are migrant urban poor from rural areas for better economic opportunities due to various reasons. In regard to the energy situation in the country, currently, around 43 percent of its population has access to electricity facilities with per capita consumption of 140 kilowatt per hour. The electricity consumption rate has increased gradually due to the rapidly growing population. Power shortage is a matter of concern in Dhaka city. The commercial establishments and industrial units in Dhaka and its adjacent areas have faced serious power crisis in some months of the year when the government innovated a 'load-management system' failing to supply uninterrupted electricity to the consumers. Even though many extra units both from the public and private sector have been added to the national grid, the power crisis is still a big issue in the country [6].

In regard to the other sources, gas is a crucial and a secure source to make energy in Dhaka city. In Dhaka, people use gas for domestic purpose, industrial purpose and for transportation. Also people started making electric current by the gas. Bangladesh spends a notable amount in importing petroleum every year to meet the local need. Petroleum price rise has always been a matter of concern for the country that is clearly connected with the price rise of all necessary products.

Bangladesh's fossil fuel consumption has increased steadily over the years. This has led carbon emission to go up. Urban air pollution is the most significant environmental issue in Bangladesh. Particulates are of the greatest concern in urban areas including Dhaka city. Old and badly maintained vehicles are critical sources of pollution. In addition to vehicular and brickfield pollution, there are several other sources of particulate pollution in Dhaka city notably: urban construction; movement of people; natural gas combustion in urban household cook-stoves; and fossil fuel burning industries in and around Dhaka city. The growing problem of solid waste in Dhaka City is another critical issue. The indiscriminate disposal of solid waste in public places causes serious environmental hazards and health risks in Dhaka city.

As in most of the developing countries, Dhaka, the capital city of Bangladesh consumes around 42 percent of the total generated electricity while the demand for electricity is approximately 12,000 megawatt and only 5,493 megawatt is on pipeline [7]. According to the available information, the demand for power in Dhaka city has increased by around 10 percent a year. As the supply is not adequate to meet the demand, adopting an alternative way to solve the crisis is the need of the time. In some neighboring and Asian countries like India and Thailand, renewable energy is a major source to meet the growing demand. However, the scenario is different in Bangladesh. Though, Bangladesh has scope to produce renewable energy, it is missing adequate policy support and initiatives.

Currently, it has been made mandatory to install solar panel to get electricity connections in new buildings in Dhaka city. Solar panels for each building might have produced notable volumes of electricity. We have also a considerably large number of shopping malls in Dhaka city where it is possible to introduce 
renewable energy for electricity generation. Furthermore, the growing real estate companies could also use environment friendly architectural design like solar energy capturing building where a substantial amount of electricity is locally produced for every building. According to Rahman and Sayeed [7] solar technology also can reduce the GHG emission rate by absorbing around 20 percent of solar radiations that might balance the inner heat of Dhaka city. However, reality is different. The solar panel in the newly constructed building is a furze. In most cases, it is just structures that hardly produce anything. Shopping malls commonly rely on non-renewable energy to meet their lavish power requirement where wastage of power and energy is very common.

The stock of gas is coming down at an alarming rate in Bangladesh. One of the main causes is the wastage of this natural resource. The wastage happens mostly in domestic use. The people who use a gas burner stove do not switch off the stove even when they are not using it. Sometimes the gas burns 24 hours a day in some cases. They even use this gas to dry their wet clothes during the rainy season. Some people do not switch off the stove just because they would need to use another match box stick to light it again. Worsening road congestion is wasting plenty of time and money - especially when considering the rising cost of gas.

There are not enough wind speed for windmills, nor is there enough river current for a hydroelectric power plant nor even any suitable semi-urban places for nuclear power station installation in Dhaka city. A nuclear power plant might be a suitable option for the bulk amount of power generation and also it has no carbon emission but it is supposed to be risky in terms of earthquake frequency. Surprisingly, Dhaka is situated in the solar radiation receiving zone on the earth with almost 335 sunny days a year. Hence, it seems that solar photovoltaic energy generation is the best option for Dhaka city to face the present energy crisis [7].

\section{Sustainable energy in Dhaka city: initiatives and relevance of green banking}

For the development of sustainable energy, Bangladesh has adequate laws and policies; some of these are directly related to environment and sustainability. Bangladesh has its National Energy Policy 1996 and National Environment Policy 1992. In regard to environmental issues, Environment Conservation Act 1995 is the umbrella act. As part of its policies, the government has also undertaken initiatives to encourage environment friendly industries and for saving scarce energy resources. In Bangladesh, a Renewable Energy Policy has been prepared in order to generate power from renewable energy sources. Various action plans have already been undertaken with the target to generate 5 percent and 10 percent of total power production by 2015 and 2020 respectively. Solar panels have already been installed in various public and private organizations including the Prime Minister's office in Dhaka city. The government planned to install solar bulbs in some of the streets of Dhaka City Corporation area. The Government has also initiated setting up a Sustainable 
Energy Development Authority (SEDA) and is working to finalize the Sustainable Energy Development Act. In 2011, the government initiated steps to replace 28 million incandescent bulbs with Compact Fluorescent Lamp (CFL) bulbs to ensure savings and proper use of power. The government is also encouraging the factories producing incandescent bulbs to gradually switch over to CFL bulbs production.

Bangladesh Bank (BB), the central bank of the country, has undertaken certain initiatives to help implement the relevant provisions of environment related acts enacted by the government of the country. Especially, the comprehensive circular (in February 2011) of BB on 'Policy Guidelines for Green Banking' is a remarkable step on the way to developing GB practices in the banking sector of the country. Besides introducing internal environment management, the banks are expected to introduce environment friendly green financing to address the environmental challenges of the country as per the framework. Some of the policy issues are directly connected with the issues of sustainable energy.

There is no doubt that environmental protection had not been on the priority list of the policy makers in Bangladesh. However, some recent initiatives by the $\mathrm{BB}$ are really encouraging. Banks have been advised to finance solar energy, biogas plant and other environment friendly projects. BB introduced Taka 2.0 billion refinance line in 2010 against bank loans for investments in solar energy, biogas plants and ETPs. In 2010, BB switched over to solar-powered lighting by setting up a 20 kilowatt solar panel, as a move towards encouraging green energy in Bangladesh [3].

In regard to the green banking practices in the country, a Bangladesh Institute of Bank Management (BIBM) survey [3] data (2012) revealed that as of June 2012, almost all banks have green banking policies and green banking cells to promote green banking activities. Up to now, banks have taken limited steps in regard to saving power and energy. However, remarkable changes have taken place in terms of awareness in this connection. Almost all banks now have a green office guide that encourages bank executives in saving energy and other economic resources. According to the BIBM survey [3], though at a limited scale, over 70 percent of banks of the country have some initiatives related to financing environment friendly projects like solar, bio-gas, Hybrid Hoffman Kiln (HHK) and Effluent Treatment Plant (ETP) projects. Some of these have started receiving the attention of entrepreneurs. For example, some composite units use poultry waste for bio gas generation for fuel and electricity; and other waste for compost fertilizer. The produced feeds of these units are used by their own poultry firms and are also sold. These composite units are doing good business in some areas.

To date, a few banks have used very insignificant portions of refinancing facilities offered by BB. The survey information reveals [3] that only five banks of the country availed refinance facilities as of June 30, 2012, and the current outstanding amount is less than BDT 25crore which is only around 15 percent of the total available amount. However, some projects financed using BB's refinancing facilities are performing well. Especially, the success of some bio- 
gas plants encouraged a number of expatriates to invest in similar projects in a nearby village of Dhaka. Moreover, it is encouraging that another 15 banks have entered into agreements with the BB to avail themselves of the facilities. Some banks have initiated green marketing or promotional activities. According to the survey information, 52 percent of banks have some kinds of promotional activities for their green initiatives. Though apparently the percentage is high, practically it covers very limited activities. There are very limited instances of NGO-linkages of banks for green causes. The sponsoring of green events by a few banks has proven to be very effective for green awareness in the country.

\section{Green banking potentials to support sustainable energy in Dhaka city and concluding remarks}

Sustainable energy development and conservation program for Dhaka city is the need of the time. The banks have great potential to support these kinds of initiatives. The specific areas could be as follows:

One, there is a crucial demand of disposing the waste of densely populated Dhaka city in a systematic manner. The waste could provide a means to producing energy, particularly the highly desired electricity. Alongside mitigating environmental hazards, these could be helpful in attaining sustainable energy. Banks could finance these projects as part of their green activities.

Two, the huge population of Dhaka city produces an enormous volume of solid human waste every day. A huge part of this total waste can be channeled into biogas systems if established in the outskirts of Dhaka. Plants can be made in and around the dumping grounds. The Central Bank of the country should encourage banks to finance these activities.

Three, currently poultry manure is produced in two areas adjoining Dhaka city. If approximately half of that can be utilized then a few small to medium sized CDM projects can be developed. The relevant CDM options have been investigated in a number of recent studies. Banks may contribute in designing the CDM projects and financing the activities.

Four, banks should promote energy saving technology and vehicles to support sustainable energy in Dhaka city. Energy efficient vehicle should receive financing by banks at relatively lower interest rate. Central Bank should support these initiatives by banks.

Five, banks have great potential to promote initiates for saving energy and power by business entities. Alongside creating pressure to undertake these energy saving activities, banks should undertake awareness development programs for producers and consumers.

Energy is one of the most important ingredients required to alleviate poverty and realize socio-economic development in any country. An energy investment policy, increased awareness, community or private sector initiative along with investment, low cost bank loans for renewable energy options and enforcement of law on energy regulation are crucial in order to handle the energy problem of the country. And in this connection, a 'bank' is an important stakeholder. An appropriate regulatory incentive structure is needed to support bank initiatives in 
this regard. The Central Bank of Bangladesh can play a pro-active role in formulating a supportive strategy for green banks in attaining a sustainable energy agenda. Practically, all stakeholders i.e. the government, Central Bank, consumer, business entities and banks are required to play pro-active roles for attaining sustainable energy in Dhaka city.

\section{References}

[1] Habib, Shah Md. Ahsan, Responsibilities of Banks in Environmental Protection in US Economy: Lessons for Bangladesh Banking Sector, Lap Lambert Academic Publishing: Germany, 2011.

[2] Habib, Shah Md. Ahsan, Green Banking Initiative: Opportunities for Bangladesh', Bank Parikrama, Vol XXX \& XXXVI, 2010.

[3] Habib, Shah Md Ahasn Habib, Md. Shahidullah and Tahmina Rahman, An Impact Evaluation of Green Banking Initiatives in Bangladesh, Banking Review Series, BIBM, 2012.

[4] Habib, Shah Md. Ahsan, Sarwar U Ahmed and Shigeru Uchida, Environmental and Social Responsibilities of Banks: Global Perspective, Economic Society 87 (2): 69-87, 2007.

[5] International Energy Agency , World Energy Outlook 2011, Special Report - Energy for All: Pari, 2011.

[6] Khairul Anam and Husnain-Al-Bustam, Renewable and Sustainable Energy in Bangladesh, Journal of Selected Areas in Renewable and Sustainable Energy (JRSE), September Edition, 2011

[7] Rahman, Md. Zahidur and Sayed Ahmed Siddiquee, Sustainable Energy for Dhaka City, The Daily Star, November 03, Dhaka, Bangladesh, 2012.

[8] Sinthia S. Ahmed, Sustainable Urban Development of Slum Prone Area of Dhaka City, World Academy of Science, Engineering and Technology 75, 2013.

[9] UN-HABITAT, Sustainable Cities Program: Sustainable Urban Mobility Component: Nairobi, 2009.

[10] UNEP, Global Green New Deal: Policy brief, March, United Nations: Geneva, Switzerland, 2009. 